\title{
Correlations between learning strategy and the ninth grade students' reading comprehension in junior high school
}

\author{
Marini Candrawati ${ }^{1}$, Baginda Simaibang ${ }^{2}$, Mulyadi $^{3}$ \\ Sekolah Menengah Pertama Negeri 01 Buay Rawan, OKU, Indonesia \\ ${ }^{223}$ Universitas PGRI Palembang
}

\begin{tabular}{|c|c|}
\hline Article Info & ABSTRACT \\
\hline Article history: & This study is limited to the investigation of the correlation between students' \\
\hline Received Jul 19 th $^{\text {th }} 2021$ & learning strategy, and reading comprehensionof the ninth grade students at \\
\hline Revised Aug $6^{\text {th }}, 2021$ & State Junior High School 01 Buay Rawan, OKU Selatan. There were 85 \\
\hline Accepted Aug $30^{\text {th }}, 2021$ & $\begin{array}{l}\text { students who has been selected as the sample of the research. The writer used } \\
\text { correlational study and formula to see the correlation between two variable }\end{array}$ \\
\hline Keyword: & $\begin{array}{l}\text { Comprehension }(Y) \text { for } 0.028 \text {. Sig. Value } 0.797 \text { was higher than Alpha value } \\
0.05(0.797>0,2146), \mathrm{H}_{\mathrm{o}} \text { was accepted and } \mathrm{H}_{\mathrm{a}} \text { was rejected. In other words, }\end{array}$ \\
\hline $\begin{array}{l}\text { Correlation } \\
\text { Learning strategies Reading } \\
\text { Comprehension }\end{array}$ & $\begin{array}{l}\text { there was no a positive correlation between Students' Learning Strategies }\left(\mathrm{X}_{2}\right) \\
\text { and Reading Comprehension(Y). It can be stated that Students Learning } \\
\text { Strategies (X) simultaneously have no significant correlated the reading } \\
\text { comprehension(Y). }\end{array}$ \\
\hline
\end{tabular}

(C) 2020 The Authors. Published by IICET.

cC)(ㄱ) This is an open access article under the CC BY-NC-SA license BY NC SA (https://creativecommons.org/licenses/by-nc-sa/4.0

\author{
Corresponding Author: \\ Marini Candrawati, \\ University of PGRI Palembang \\ Email: ican453@gmail.com
}

\section{Introduction}

In First of all, reading activity should be given more attention and that teaching and learning in the classroom should focus on the development of the students' reading skill. in addition, [1] state that reading comprehension is a process of making sense of written ideas through meaningful interpretation and interactions with language in the form sentences and paragraph. According to [2], reading is the act of constructing meaning while interacting with text, just as we use information stored in schemana to understand and interact with the world around us, so the teachers use this knowledge to a make sense out of printed language.

The students are considered as the objects. In fact, the consideration of the roles of the students in very important for the success of learning [3]. The students are considered as the subject of teaching and learning, not the object. As the object they are expected to be active in the teaching and learning process. The importance of language learning strategies for the success and effectiveness of language learning. Effective language learners generally use proper learning strategies, and the use of learning strategies help the students' learning result. The importance of beliefs and strategies in language learning indicates that it is important for the teacher to know what beliefs and strategies of the students in learning language and the correlation of them. If the writer looks at these points, it seems that the students' leaning strategy and motivation can effect activities teaching and learning process. 
Correlations Between Learning Strategy...

In relation to this idea, it appears a question whether language learning strategy and learning motivation correlate reading comprehension. The writer is interested in focusing on the study entitle "Correlation among Learning Strategy, Learning Motivation and the ninth grade Students' Reading Comprehension of State Junior High School 01 Buay Rawan, OKU Selatan".

\section{Objective of the Study}

The objectives of the study are to find out whether or not There is significant correlation between learning strategy and reading comprehension of the ninth grade students at State Junior High School 01 Buay Rawan, OKU Selatan.

\section{Research Problem}

Is there any significant correlation between learning strategy and reading comprehension of the ninth grade students at StateJuniorHighSchool01 Buay Rawan, OKU Selatan?

\section{Significance of the Study}

This study is expected give some benefits to the English teacher and the students themselves:

1. Give information to the English teachers about students' process information, plan, and select the most suitable strategy to understand or to solve a problem and Give contribution to the development of English teaching learning process.

2. It is expected that students will be encourages and motivate to apply learning strategy and learning motivation to improve their reading comprehension.

\section{Method}

In this study the writer will use descriptive method because the writer will investigate the effect of prediction variables on the criterion variable with a correctional study. the population of this study is ninth grade students of State Junior High School 1 Buay Rawan, OKU Selatan in academic 2020/2021. The sample of this research will take purposive sampling [4]. The sample will take $35 \%$ in every the ninth grade students at State Junior High School 01 Buay Rawan OKU Selatan.

In this study, in collecting the data the writer will use two kinds of instrument (1) questionaires and (2) reading test. The reading test instrument is in multiple choice questions with four options for each question. The score of students' reading comprehension test will be obtained from this following formula:

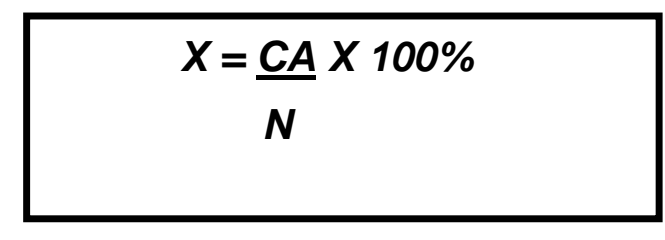

Legends: $\quad \mathrm{X} \quad$ : Students' individual score.

CA : Students' correct answer.

$\mathrm{N} \quad$ : Total number of test.

Data tool that is collected in quantitative research to measure the subject that will be observed can be conducted by giving the test[5]. In this study, the data were collected by giving questionnaires and reading comprehension test. Assessment technique, the most widely employed strategy scale, the ESL/EFL version of the Strategy Inventory for Language Learning (SILL) has been used. Reliability of the SILL is high across many cultural groups. Validity of the SILL rests on its predictive and correlative link with language performance (course grades, standardized test scores, ratings of proficiency), as well as its confirmed relationship to sensory preferences. 


\begin{tabular}{|c|c|c|}
\hline \multirow[t]{2}{*}{ N } & val1a & ס ס \\
\hline & Missing & 0 \\
\hline \multicolumn{2}{|l|}{ Mean } & 195,19 \\
\hline \multicolumn{2}{|c|}{ Std. Error of Mean } & 1,340 \\
\hline \multicolumn{2}{|c|}{ Median } & 194,00 \\
\hline \multicolumn{2}{|l|}{ Mode } & 194 \\
\hline \multicolumn{2}{|c|}{ Std. Deviation } & 12,353 \\
\hline \multicolumn{2}{|l|}{ Variance } & 152,607 \\
\hline \multicolumn{2}{|l|}{ Kurtosis } &, 524 \\
\hline \multicolumn{2}{|c|}{ Std. Error of Kurtosis } &, 517 \\
\hline \multicolumn{2}{|l|}{ Range } & 66 \\
\hline \multicolumn{2}{|l|}{ Minimum } & 162 \\
\hline \multicolumn{2}{|l|}{ Maximum } & 228 \\
\hline \multicolumn{2}{|l|}{ Sum } & 16591 \\
\hline \multirow[t]{3}{*}{ Percentiles } & 25 & 189,00 \\
\hline & 50 & 194,00 \\
\hline & 75 & 200,00 \\
\hline
\end{tabular}

In this study, the writer focuses in content validity and constructs validity. The instrument used in this study wasreadymade test and ready-made questionnaires. To making the test to be valid, the writer would use content validity, where it is refers to the nature of the content include within the instrument and the specification, and the writer use to formulate the content.

\section{Reliability Test}

According[6] reliability refers to the consistency of the scores obtained how consistent they are for each individual from one set of items to another. Before doing the research, the writer does some try-outs to know the reliability of questionnaires and test items.

According [6], states that if the reliability coefficient is more than $0,70(\mathrm{KR} 21>0,70)$, the test items are considered reliable, but if less than $0,70(\mathrm{KR} 21<0,70)$, they are unreliable.

\section{Data Analysis}

In this study the writer will use r-Product Moment and Multiple Regression to apply in the data analysis with regard through the formulation of problems.

\section{Normality Test}

The criterion is $\mathrm{H}_{\mathrm{o}}$ is accepted id $\mathrm{Sig}>\alpha(0.05)$, it means that the data have normal distribution.

\section{Homogeneity Test}

The writer should know whether the sample of the research will behomogeneous or not, and measure the homogeneity use SPSS and the criterion are $\mathrm{H}_{\mathrm{o}}$ is accepted is $\mathrm{Sis}>\alpha(0.05)$ or Fcount $<$ Ftable, it means that the data are homogenous.

\section{Linearity Test}

The linearity test aims to determine whether two variables (independent and dependent variables) have a linear correlation or not. 
Correlations Between Learning Strategy...

\begin{tabular}{|c|c|c|}
\hline \multirow[t]{2}{*}{$\mathrm{N}$} & Valid & 85 \\
\hline & Missing & 0 \\
\hline \multicolumn{2}{|l|}{ Mean } & 17,72 \\
\hline \multicolumn{2}{|c|}{ Std. Error of Mean } &, 120 \\
\hline \multicolumn{2}{|c|}{ Median } & 18,00 \\
\hline \multicolumn{2}{|c|}{ Mode } & 18 \\
\hline \multicolumn{2}{|c|}{ Std. Deviation } & 1,109 \\
\hline \multicolumn{2}{|c|}{ Variance } & 1,229 \\
\hline \multicolumn{2}{|l|}{ Kurtosis } & 2,222 \\
\hline \multicolumn{2}{|c|}{ Std. Error of Kurtosis } &, 517 \\
\hline \multicolumn{2}{|l|}{ Range } & 6 \\
\hline \multicolumn{2}{|l|}{ Minimum } & 14 \\
\hline \multicolumn{2}{|l|}{ Maximum } & 20 \\
\hline \multicolumn{2}{|l|}{ Sum } & 1506 \\
\hline \multirow[t]{3}{*}{ Percentiles } & 25 & 17,00 \\
\hline & 50 & 18,00 \\
\hline & 75 & 18,00 \\
\hline
\end{tabular}

\section{Multiple Regressions}

Multiple Regression will be applied to test whether variables $\mathrm{X}_{1}$ (learning strategies) have significant correlation with variable Y (reading comprehension).

\section{Results and Discussions}

\subsection{The Result of Students Learning Strategies}

The data of learning strategies were collected by using a questionnaire. The maximum score of test was 228 , the minimum score of test was 162 , and the range was 66 . The mean (or the average score) and standard deviation were 195,19 and 12,353 respectively.

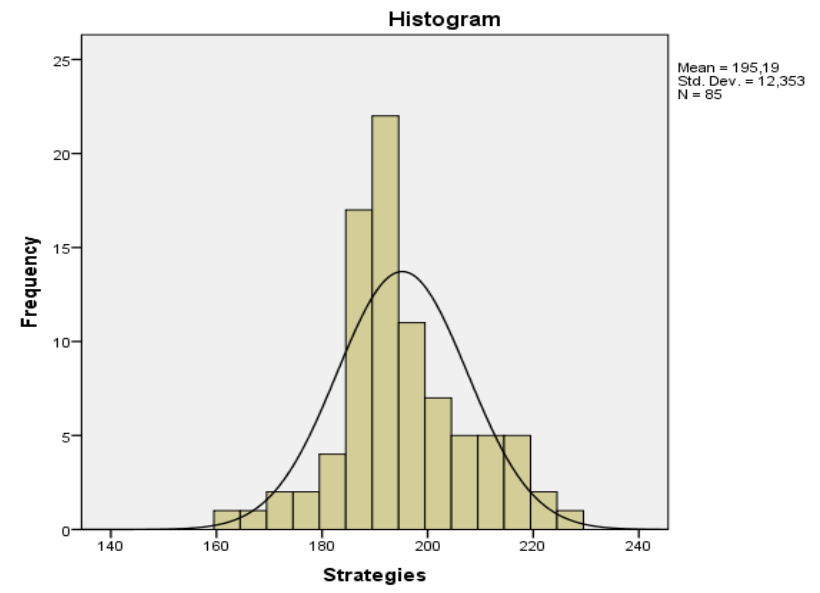




\section{Figure 3 Histogram of the Score of Learning Motivation}

The frequency data are often effectively displayed by histogram. The data from table 12 are presented as a histogram in figure 3 above. In this histogram, the vertical dimension on the graph list the frequency of the score, and the horizontal dimension rank order the score of learning motivation from the lowest to the highest. The columns are drawn in the graph to correspond with the result of the computation the data.

\section{4,2 The Result of Students Reading Comprehension}

The data of learning strategies were collected by using a test. The maximum score of test was 20 , the minimum score of test was 14 , and the range was 6 . The mean (or the average score) and standard deviation were 17,72 and 1,109 respectively.

Statistics Formula r-Product Moment

4.2 Correlation between Students LearningStrategies $(X)$ and Reading Comprehension $(Y)$

Table 20 Correlation between Students' Learning

Strategies $\left(X_{2}\right)$ and Reading Comprehension $(Y)$

One-Sample Kolmogorov-Smirnov Test

\begin{tabular}{|ll|r|}
\hline & & $\begin{array}{r}\text { Unstanda } \\
\text { rdized } \\
\text { Residual }\end{array}$ \\
\hline $\mathrm{N}$ & Mean & 85 \\
Normal Parameters &, 0000000 \\
& Std. & 1,108092 \\
& Deviation & 76 \\
Most Extreme Differences & Absolute &, 246 \\
& Positive &, 206 \\
Test Statistic & Negative & -246 \\
Asymp. Sig. (2-tailed) & &, 246 \\
\hline
\end{tabular}

a. Test distribution is Normal.

b. Calculated from data.

c. Lilliefors Significance Correction.

Table 16 showed the value of the coefficient correlation between Students' Learning Strategies (X)and Reading Comprehension(Y) for 0.027. Sig. Value 0.806 was higher than Alpha value $0.05(0.806>0,2146), H_{a}$ was rejected and $\mathrm{H}_{\mathrm{o}}$ was accepted. In other words, there was not significant correlation between Students' Learning Strategies (X)and Reading Comprehension(Y).

\section{Normality Test}

\subsection{The Correlation between Students' Learning Strategies $\left(X_{2}\right)$ and Reading Comprehension( $(Y)$}

Ho: There is not any significant correlation between 
Correlations Between Learning Strategy...

- Table 24Test Homogeneity of The Students' Score

Learning Strategies $\left(X_{2}\right)$

Test of Homogeneity of Variances

\begin{tabular}{|c|c|c|c|}
\hline Levene Statistic & df1 & $\mathrm{df} 2$ & Sig. \\
\hline 122,800 & 4 & 80 & ,000 \\
\hline
\end{tabular}

learning strategy and reading comprehension of the ninth grade students at State Junior High School 01 Buay Rawan, OKU Selatan.

$\mathrm{Ha}$ : There is significant correlation between learning strategy and reading comprehension of the ninth grade

Table 16 Correlation Students Learning Strategies $(X)$ and

Reading Comprehension(Y)

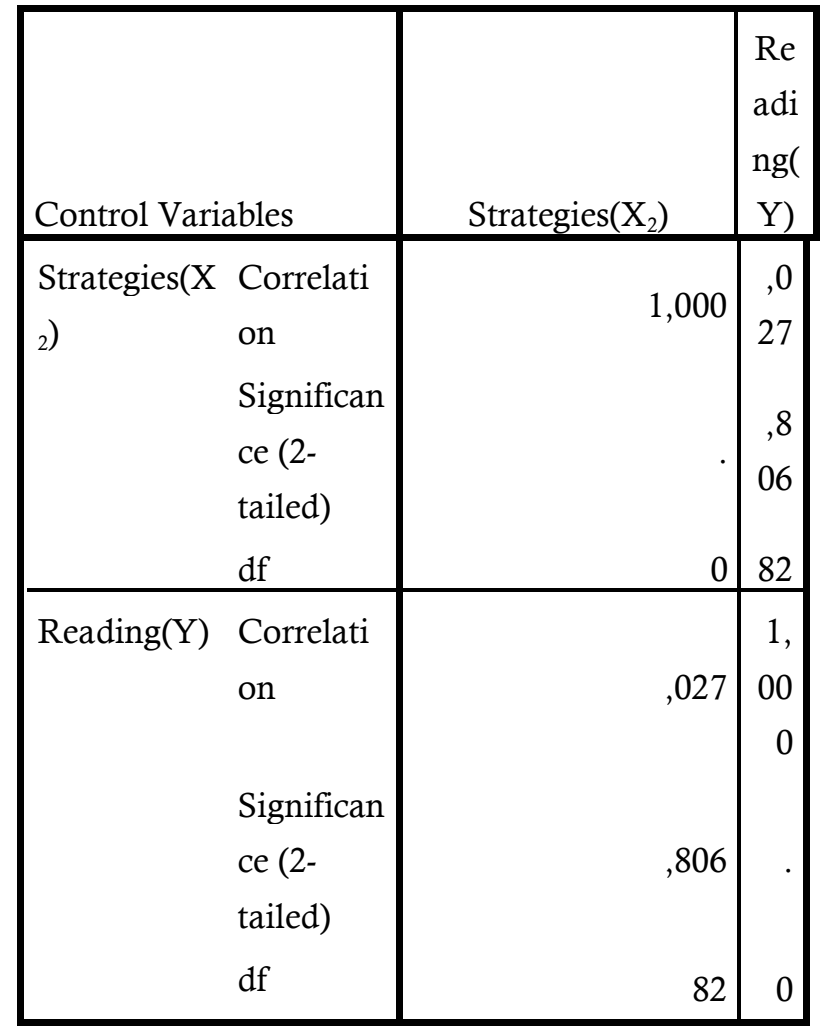

students at State Junior High School 01 Buay Rawan, OKU Selatan

From the table 17 showed that the coefficient correlation $\mathrm{X}_{2}$ and $\mathrm{Y}$ with Asymp sig. (2-tailed) or $\mathrm{P}_{\text {value }}$ was $0.000<0.05$ its' meant that the data distribution was not normal. Finally, the writer concluded that $\mathrm{H}_{\mathrm{o}}$ was accepted and $\mathrm{H}_{\mathrm{a}}$ was rejected so there was not significant correlation between students' learning strategies and reading comprehension of the ninth grade students at State Junior High School 01 Buay Rawan, OKU Selatan.

\section{Homogeneity Test}

Levence Statistic found in SPSS 22 is used to determine the sample are homogeneous or not. The sample are considered homogeneous whenever the $p$-value is higher than mean significant differences at the 0.05 level.

\section{The Students' Score Learning Strategies}

Based on the table 24, the calculation of Levence Statistic by using SPSS 22, it was found that the Sig. Value was 0.000. It is assumed that the students' score learning strategies are not homogeneous since Sig. 
Table 27 Linearity Test Correlation of Students' Learning

Strategies $\left(X_{2}\right)$ and Reading Comprehension $(Y)$

ANOVA Table

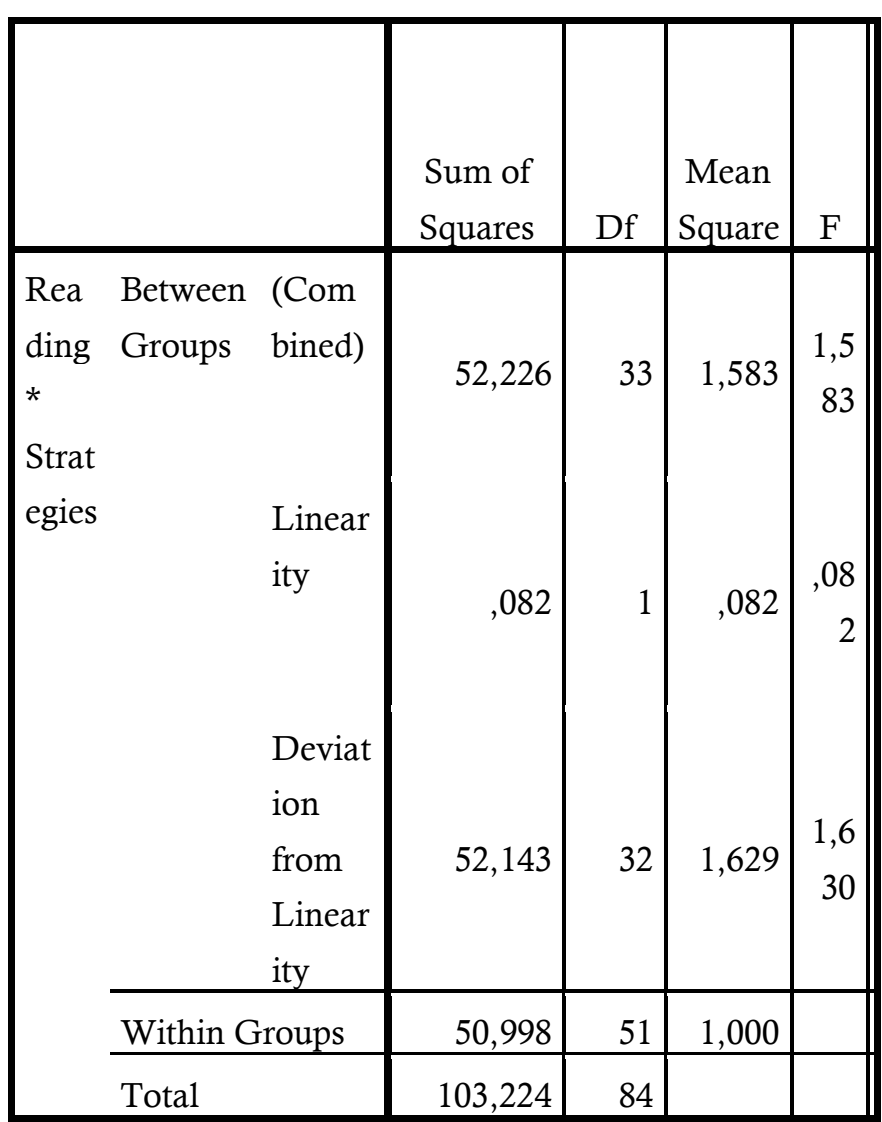

Value is lower than the mean significant difference at the 0.05 level $(0.2146)$.

\section{Linearity Test}

This test is done in order to know whether the predictor (Independent variables) and criterion (Dependent variable) had linear correlation or not. The determination was done based on the comparison of $p$-value that was shown at Sig. column on deviation from linearity in the output of SPSS Statistic application. If $p \leq 0.05$, it indicated there was not any linear relationship. And if $p \geq 0.05$, it indicated there was linear relationship between the variables.

\subsection{Linearity Test of the Correlation of Students' Learning Strategies on Reading Comprehension}

Based on the linearity table above, the Sig. deviation from linearity was $0.059<0.05$. it could be conducted that the correlation of Students' Learning Strategies $\left(\mathrm{X}_{2}\right)$ on Reading Comprehension $(\mathrm{Y})$ was not linear.

Table 25 Homogeneity Test of The Students' Score

Reading Comprehension (Y)

Test of Homogeneity of Variances

\begin{tabular}{|c|c|c|c|}
\hline Levene Statistic & $\mathrm{df} 1$ & $\mathrm{df} 2$ & Sig. \\
\hline 138,516 & 4 & 80 & ,000 \\
\hline
\end{tabular}


Correlations Between Learning Strategy...

The results for the variable Students Learning Strategies $\left(\mathrm{X}_{2}\right)$ obtained coefficient $\mathrm{B}=0.002$ and calculate the $t_{\text {obtained }}=0.246$ or p-value $=0.806$, because $0.806>0.05$. $\mathrm{H}_{\mathrm{o}}$ was accepted, the error level $\alpha=0.05$ or $5 \%, \mathrm{H}_{\mathrm{a}}$ was rejected. It can be stated that Students Learning Strategies $\left(\mathrm{X}_{2}\right)$ simultaneously have no significant correlated the reading comprehension $(\mathrm{Y})$.

\section{Conclusions}

The results for the correlation about Students' Learning Strategies (X) and Reading Comprehension (Y) for 0.028. Sig. Value 0.797 was higher than Alpha value $0.05(0.797>0,2146), H_{o}$ was accepted and $H_{a}$ was rejected. In other words, there was no a positive correlation between Students' Learning Strategies (X) and Reading Comprehension(Y). It can be stated that StudentsLearning Strategies (X) simultaneouslyhave no significant correlated the reading comprehension $(\mathrm{Y})$.

\section{References}

Arikunto, Suhaimi. 2005. ProsedurPenelitian. Jakarta: PT. RinekaCipta.

Fraenkel, Jack. R., and Norman E. Wallen. 2012. How to Design and Evaluate Research in Education 8thEdition. Boston: McGraw-Hill Higher Education.

Fraenkell, J. R., \&Wallen, N. E. (1991). Quantitative Research in Social Studies Education. In j. P. Shaver (ed.). Handbook of Research on Social Studies Teaching and Learning (pp. 67-97). New York, NY: MacMillan.

Marlina, Heilman, A. W., Blair, T. R., \&Rupley, W. R.bv iii vz xc (2002).Principles and Practices of Teaching Reading (10th ed.). Upper Saddle River, NJ: Merrill=Prentice Hall.

Nunan, D. (2003). Nine Steps to Leaner Autonomy. In Nunan, D. [Ed.]. Practical English Language Teaching. New York. McGraw Hill.

Ruddell, M. R. (2005). Teaching Content Reading and Writing, (4th ed.). New York: John Wiley \& Sons Canada, Ltd. 